\title{
Sciendo
}

Administration, vol. 68, no. 3 (2020), pp. 57-59

doi: 10.2478/admin-2020-0016

\section{Tom Hardiman}

Tom Hardiman, who died in May 2020, made a significant contribution to Irish public life, most notably as Director General of RTÉ, but also in an impressively wide-ranging number of public policy areas, including industrial development, higher education, telecommunications and international relations.

Tom commenced his career with the then Radio Éireann in 1952 soon after graduating from University College Dublin. $\mathrm{He}$ subsequently moved to RTÉ television. He was the engineer in charge of the inaugural broadcast of Teilifís Éireann from the Gresham Hotel, Dublin, in 1961. He became Director General in 1968 at the age of thirty-nine.

His time at the head of RTÉ was a period of development for the broadcaster, including the establishment of Raidió na Gaeltachta, which he enthusiastically supported, and the launch of colour television. It also included the initial period of turmoil in Northern Ireland and ongoing tensions between government and the national broadcaster over its news coverage. This culminated in the sacking of the RTÉ Authority in November 1972 by the government led by Jack Lynch, as a result of controversy occasioned by the refusal of journalist Kevin O'Kelly to hand over tapes to the Gardaí of an interview he carried out with a self-professed leading Provisional IRA leader. Throughout his tenure Tom was a committed defender of the editorial independence of the national broadcaster.

When he left RTÉ in 1975 Tom worked in a range of private sector roles, also serving as President of the Confederation of Irish Industry, the Marketing Institute and the Dublin Chamber of Commerce. But he also maintained his contribution to the public service. He chaired the National Board for Science and Technology and was also 
active on the National Planning Board and Telecommunications Review Group.

Tom chaired the Commission on Technological Education which oversaw the development of the National Institutes for Higher Education (NIHEs). He also chaired the government-appointed International Study Group, the recommendations of which led to the eventual transition of the NIHEs to full university status. NIHE Dublin was awarded university status in 1989 and became Dublin City University (DCU). Tom was elected as the first Chancellor of DCU, and played an important role in the development of the university.

Tom also had a keen interest in international relations and Ireland's role and potential contribution in Europe and beyond. $\mathrm{He}$ actively promoted Irish-Asian relations and chaired the Asia Europe Foundation. He had a particular interest and close relationship with Japan, resulting in his being awarded the Japanese Order of the Rising Sun in 1986, only the second European to be so honoured. His interest in Asia and also in the arts led to him being asked to serve as Chairman of the Chester Beatty Library.

Similar to other senior public servants who played an influential role in the development of modern Ireland, Tom was highly educated in the classical sense of the term. He spoke Irish fluently and could read Latin with ease. An engineer by profession, he was also knowledgeable in economics, the arts, literature and religion. The hallmark of a career which spanned seven decades was a commitment to public service and 'serving the state'. However, other key characteristics were his capacity for leadership, his exceptional ability for mediation, in bringing disparate opinion together, and lastly his ability to 'get things done' - a skill the value of which cannot be underestimated in the public service.

Tom was also a good friend of the Institute of Public Administration (IPA) and committed to the concept of public service reform. In 1990, with the aim of contributing to reflection on improving public sector performance, Tom, together with Dr Michael Mulreany of the Institute, organised a conference on the theme of 'Efficiency and Effectiveness in the Public Domain'. The conference proceedings were subsequently published by the IPA. ${ }^{1}$ In the foreword, Tom comments that 'the search for increased efficiency and effectiveness has brought with it the need to clarify objectives and set

${ }^{1}$ Hardiman, T. P., \& Mulreany, M. (1991). Efficiency and effectiveness in the public domain. Dublin: Institute of Public Administration. 
priorities, to evaluate outputs rather than concentrate on controlling inputs, to improve managerial information and develop concepts of managerial accountability, and to take account of consumer satisfaction with the quality of the services delivered'. It is a commentary that still resonates today.

Joanna O'Riordan 